\title{
Medication reconciliation in emergency department - the role of clinical pharmacist
}

\author{
Amanda Veiga BARBOSA ${ }^{1}$ (D), Daniele Silva SZPAK ${ }^{1}$ (D) Pedro Paulo CHRISPIM ${ }^{1}$ (D) \\ ${ }^{1}$ Hospital do Coração-HCor, São Paulo, Brasil \\ Corresponding author: Barbosa AV, amandaveigab@gmail.com \\ Submitted: 17-02-2021 Resubmitted: 08-03-2021 Accepted: 09-03-2021
}

Peer review: blind reviewer and Maria Rita Novaes

\begin{abstract}
Objective: To classify the frequencies and types of pharmaceutical interventions related to medication reconciliation performed in the hospital emergency room. Methods: This is a retrospective sectional study of medication reconciliation carried out in the emergency department of a referral hospital in cardiology from June 11 to August 11, 2019. All patients admitted to the sector at the corresponding period and that have been reconciled were selected for the study. Patients' home medications were classified according to the Anatomical Therapeutic Chemical Classification and as reconciled, not reconciled or reconciled after pharmaceutical intervention. Types of pharmaceutical interventions considered: suggestions for correcting the omission of patients' home medications, dose or frequency. Interventions were classified as accepted or not accepted. The patients were divided into two groups: no discrepancies or intentional discrepancies (G1) and unintentional discrepancies (G2). The groups were compared using the Student's T test (continuous data) and chi-square ( $\times 2$ ) or Fisher's exact test (categorical variables), considering statistical significance values of $p<0.05$. Results: 182 admissions were analyzed, with an average number of patient's home medications use of $4.9 \pm 3.6$ drugs per patient. Of the 900 patients' home medications, discrepancies were found in 227 medications on medical prescription of admission at the emergency room, being $48.9 \%$ intentional discrepancies and $51.1 \%$ unintentional discrepancies. Regarding unintentional discrepancies, $81 \%$ were due to the medication's omission correction on the medical prescription; $9.5 \%$ were correction of divergent dose of patients' home medications and frequency of administration respectively and all were adjusted after pharmaceutical intervention. 139 pharmaceutical interventions were performed to correct medication discrepancies, with $83.5 \%$ of acceptance by medical staff. Among all the analyzed medications, $51.8 \%$ had at least one registration failure by medical and/or nursing staff. Conclusion: The presence of the pharmacist in the emergency room reduced the incidence of unintentional discrepancies related to medication reconciliation, through interventions to correct medication omissions, dose and frequency, being an important element for patient safety.
\end{abstract}

Key words: medication reconciliation; emergency service; hospital; clinical pharmacists.

\section{Reconciliação medicamentosa no pronto socorro - atuação do farmacêutico clínico}

\section{Resumo}

Objetivos: Identificar e classificar as frequências e tipos de intervenções farmacêuticas relacionadas a reconciliação medicamentosa realizadas no pronto socorro hospitalar. Métodos: Estudo retrospectivo seccional das reconciliações medicamentosas realizadas no pronto socorro de um hospital referência em cardiologia no período de 11 de junho a 11 de agosto de 2019. Foram selecionados para o estudo todos os pacientes admitidos no setor e período correspondente e que foram reconciliados. Os medicamentos de uso contínuo dos pacientes foram classificados conforme a Classificação Anatômico Terapêutico Químico e em reconciliados, não reconciliados ou reconciliados após intervenção farmacêutica. Foram consideradas tipos de intervenções farmacêuticas: sugestões para correção de omissão de medicamentos de uso contínuo dos pacientes, dose ou frequência dos mesmos. As intervenções foram classificadas em aceitas ou não aceitas. Os pacientes foram divididos em dois grupos: sem discrepâncias ou discrepâncias intencionais (G1) e com discrepâncias não intencionais (G2). Os grupos foram comparados através do teste de T de Student (dados contínuos) e qui-quadrado $\left(x^{2}\right)$ ou teste exato de Fisher (variáveis categóricas), considerando significância estatística valores de $p<0,05$. Foram analisadas 182 admissões, com um número médio de medicamentos de uso contínuo de 4,9 93,6 medicamentos por paciente. Dos 900 medicamentos de uso contínuo dos pacientes, foram encontradas discrepâncias em 227 medicamentos na prescrição médica na admissão pelo pronto socorro, sendo 48,9\% discrepâncias intencionais e 51,1\% discrepâncias não intencionais. Em relação às discrepâncias não intencionais 81\% foram de correção de omissão do medicamento na prescrição médica; 9,5\% de correção de dose divergente do uso contínuo do paciente e frequência de administração respectivamente e todas foram ajustadas após intervenção farmacêutica. Foram realizadas 139 intervenções farmacêuticas para corrigir as discrepâncias medicamentosas, com 83,5\% de aceitação pela equipe médica. Dentre 
todos os medicamentos analisados, $51,8 \%$ tinha pelo menos uma falha de registro pela equipe médica e/ou de enfermagem. A presença do farmacêutico no pronto socorro reduziu a incidência de discrepâncias não intencionais relacionadas à reconciliação medicamentosa, através de intervenções para correção de omissão de medicamentos, ajuste de dose e frequência, sendo um importante elemento para a segurança do paciente.

Palavras-chave: reconciliação de medicamentos; serviços médicos de emergência; farmacêuticos clínicos.

\section{Introduction}

Medication reconciliation is one of the activities carried out by the pharmacist within the health institutions. It is about obtaining a complete history of patients' home medication, with name, dose, frequency, route and time of administration, reconciling this information with the medical record and the medical prescription. In the hospital environment, medication reconciliation occurs at admission, in the transfers between inpatient units and at hospital discharge. ${ }^{2}$ The purpose of this practice is to reduce medication errors, such as duplications or omissions, avoiding harms and potential risks to the patients. ${ }^{3}$

The Joint Commission for Accreditation of Healthcare Organizations (JCAHO) considers medication reconciliation as a strategic clinical practice to improve patient safety and reduce medication errors. ${ }^{4}$ Approximately $27 \%$ of the medication errors in hospitals can be attributed to incomplete collection of medication history at the time of the patient's admission, which can result in the interruption of treatment for previous diseases or in inadequate therapy during hospitalization.

Since the emergency department is one of the main routes of hospital admission for the patient, the presence of the pharmacist in this sector can reduce the incidence of medication errors related to medication reconciliation. ${ }^{6,7}$ In Brazil, a study conducted by a large private hospital concluded that the clinical pharmacy service in the emergency department has improved patient safety and the prevention of adverse events through pharmaceutical interventions. ${ }^{8}$

A pharmaceutical intervention is planned, documented and performed with the user and the health professionals, aiming to solve or prevent problems that interfere or may interfere with pharmacotherapy, beinganintegral partofthe pharmacotherapeutic monitoring/follow-up process. ${ }^{9}$ Pharmaceutical interventions with the medical and multidisciplinary team significantly reduce medication errors. ${ }^{10}$

However, despite the relevance of the topic for the clinical practice of the professional pharmacist, studies on the implementation of medication reconciliation in Brazilian emergency services are still scarce. In this context, the need to conduct a study on the theme was verified. The objective was to identify and classify the frequencies and types of pharmaceutical interventions that were required by the medication reconciliation procedures performed in the emergency department.

\section{Methods}

This is a retrospective and observational study of the medication reconciliations performed in the Pediatric and Adult Emergency Department of a hospital that is a reference in cardiology in the city of São Paulo, from June $11^{\text {th }}$ to August $11^{\text {th }}, 2019$. All the patients admitted to the emergency department in the corresponding period and who were reconciled in the sector were selected for the study.
The initial information analyzed was the following: number of the punctual service offered, date of hospitalization, diagnostic hypothesis at the time of admission classified by ICD-10, demographic information, and patients' home medication classified according to the Anatomical Therapeutic Chemical Classification (ATC). The medications were further classified into: prescribed (when the medication was present in the current medical prescription, in the dose and frequency according to the patient's continuous use), not prescribed (when it was not present in the current medical prescription of the day) or prescribed only after the pharmaceutical intervention. The data were collected by consulting the patients' medical records (medical admission sheet; nursing admission sheet, pharmaceutical evolution, and the medical prescription in force that day).

The types of pharmaceutical interventions were considered as verbal suggestions to the medical team (registered in the pharmaceutical evolution) for the correction of the omission of patients' home medication, dose or frequency, carried out by the resident pharmacist present in the sector. The pharmaceutical interventions were conducted at the time of the patient's admission to the emergency department. Pharmaceutical interventions for all the patients' home medication were considered. The pharmaceutical interventions were classified as accepted when there was agreement between the registered suggestion and the change in the current prescription at admission by the medical team, or as not accepted. In situations where there was a record of the clinical reason for suspension or modification of the continued-use medication (for example, patient using warfarin continuously and internal use due to bleeding or enlarged INR), the discrepancy was classified as intentional. Unintentional discrepancies occurred when the medical team was unaware of the patient's continuous use of the medication or when, due to neglect, did not pay attention to prescribe. Medications prescribed at different doses or frequencies other than those used continuously by the patient were also classified as unintentional discrepancies, without recording the clinical reason. ${ }^{11}$ Failure to record the medications was also evaluated by comparing the records of the analyzed documents.

Possible selection bias may have occurred but, since all the patients seen by the Pharmacist were analyzed, the selection of patients could be affected only by the seasonality of demand for the ED, which had been partially resolved with collection for over a month, leaving possible annual seasonal effects and differences in the profile of patients seen during business hours or those who seek care at night and on Sundays. The study was not affected by the SARS-CoV2 pandemic, as it was developed in 2019. Follow-up was not a problem, given that only visits to the ED were evaluated. Patients discharged or definitively admitted to the hospital were not included. Finally, all the analyses were planned a priori, resulting in no deviations from the initial objectives.

Sample size was selected for convenience. The patients were divided into two groups for data analysis: without discrepancies or intentional discrepancies (G1) and with unintentional discrepancies (G2). The statistical treatment of the data was performed 
through the Microsoft Office Excel 365 (Microsoft Corporation, USA) software, with descriptive statistics and comparison being performed through the Student's t test (continuous data) and chisquare $\left(x^{2}\right)$ or Fisher's exact test (categorical variables). Statistical significance will be considered for $p$-values $<0.05$.

The study was approved by the Ethics Committee of Hospital do Coração - HCor, in January 2020 (CAAE: 28384320.3.0000.0060), with exemption from the application of the Free and Informed Consent Form (FICF) for being a retrospective, observational and non-interventionist study, with data collection by medical record review.

\section{Results}

The medical charts of 179 of the 998 patients that were admitted to the emergency department in the period of two months were analyzed, totaling 182 admissions, since some patients were admitted more than once in the corresponding period. The age of the patients was $63 \pm 19$ years old (mean age \pm SD) and $63.2 \%$ were male. Only one pediatric patient who was admitted to the emergency department was included in the study. The main diagnostic hypotheses at the patients' admission were classified according to ICD-10. Some patients received more than one diagnostic hypothesis at admission, totaling 205 diagnostic hypotheses. The diagnostic hypotheses are described in Table 1 by proportion of occurrence.

Of the total of patients, 157 (87.7\%) reported making continuous use of medications. The mean number of patients' home medication was $4.9 \pm 3.6$ medications per patient. The patients' home medication are classified according to the Anatomical Therapeutic Chemical (ATC) Classification, in its first level. Most of the medications that the patients take on a continuous basis are cardiovascular medications. The complete classification is shown in Table 1, in the Pharmacotherapy category.

In total, 900 patients' home medication were analyzed. Of these, 466 medications (51.8\%) had at least one registration failure by the medical and/or nursing team on their respective admission sheets in the emergency department. The registration failures are shown in Table 1 and were divided by the professional involved.

Discrepancies were found in 227 medications, with 111 intentional discrepancies (48.9\%) and 116 unintentional discrepancies $(51.1 \%)$ in the medical prescription at admission to the emergency department. Regarding the total number of medication discrepancies, 139 pharmaceutical interventions were performed to correct them, with $83.5 \%$ of acceptance by the medical team. Pharmaceutical interventions were carried out related to medication discrepancies without clinical justification or that were not described in the medical record. Regarding the 116 unintentional discrepancies, all were adjusted after pharmaceutical intervention and 94 (81.0\%) were for correcting the omission of the medication in the medical prescription; 11 (9.5\%) were corrections of divergent dose of continuous use by the patient, and 11 (9.5\%) were corrections of administration frequency divergent in the prescription. The 23 pharmaceutical interventions related to the intentional discrepancies were not accepted by the medical team, with verbal justification after the intervention, Table 1 . The verbal justifications reported by the medical team were evolved in medical records by the resident pharmacist.

\section{Discussion}

This study described the types and frequencies of pharmaceutical interventions performed in relation to medication reconciliation in the emergency department. The medication reconciliation process is recognized by international organizations such as the Institute for Healthcare Improvement (IHI) and the Joint Commission Accreditation of Healthcare Organizations (JCAHO) as a gold standard activity for patient safety, ensuring care continuity and reducing the risk of harms. ${ }^{12,13}$

Most (81\%) of the interventions were to correct the omission of patients' home medication that were absent from the medical prescription at hospital admission, followed by dose correction $(9,5 \%)$ and, finally, correction of administration frequency $(9,5 \%)$ divergent from the patient's continuous use. A similar study, carried out by Kent AJ et al, showed that $66 \%$ of the discrepancies in the medical prescription for admission to the emergency department compared to the list of patients' home medication were related to the omission of these medications in the prescription, also followed by the incorrect dose and frequency ( $11 \%$ each). ${ }^{7}$

In other studies, the rate of medication omission in the prescription by the medical team was also the type of medication discrepancy most frequently found and which demanded the greatest number of pharmaceutical interventions. ${ }^{12,13}$ The rate of medication discrepancy in the dose and frequency of the patients' home medication of patients is also similar to that found in the literature. ${ }^{14}$ These discrepancies can damage the efficacy and safety of the patient's treatment, including interruptions in the treatment of chronic conditions and an increased likelihood of worsening untreated comorbidities. ${ }^{15}$

The omission of medications in the prescription can be related to the collection of incomplete and inaccurate medication history. ${ }^{15}$ Among the medication analyzed, 51.8\% had some registration failure in the medical records, either by the medical and/or nursing team. The group with unintentional discrepancies presented a higher incidence of registration failures $(p<0.05)$, the main failure found being absence of registration. A study conducted by Salinitro el al. on medication reconciliation showed that, in $42 \%$ of the patients evaluated, there were registration failures of the medication history by the medical team. ${ }^{16}$ Incomplete or inaccurate acquisition of the patient's medication history can lead to medication discrepancies, possible medication errors and implications for patient safety. ${ }^{17}$

Studies on the acceptance rates of pharmaceutical interventions demonstrate great variability of these numbers, with rates between $50 \%$ and $99.5 \%$ of the total interventions. ${ }^{18-20}$ This study found an acceptance rate of $83.5 \%$ by the medical team in the total of interventions for medication discrepancies, and all the interventions related to unintentional discrepancies were accepted. The interventions that were not accepted were related to discrepancies in which there was no record in the medical chart of the clinical reason for their occurrence, which warns of the need for institutional initiatives to optimize the medical record of medication reconciliation, including continuing education actions. A recently published meta-analysis on medication reconciliation of patients admitted to the emergency department evidenced that the pharmaceutical interventions significantly reduced the number of medication discrepancies in medical prescriptions, demonstrating the benefits of having a medication reconciliation process conducted by a clinical pharmacist. ${ }^{21}$ 
Table 1. Information of the medication reconciliations of the admissions conducted in the emergency department in the period from June $11^{\text {th }}$ to August $11^{\text {th }}, 2019$.

\begin{tabular}{|c|c|c|c|c|}
\hline \multirow[b]{2}{*}{ Information } & \multirow[b]{2}{*}{ All } & \multicolumn{2}{|c|}{ Medication reconciliations } & \multirow[b]{2}{*}{ p-value } \\
\hline & & $\begin{array}{l}\text { Without discrepancies } \\
\text { or with intentional } \\
\text { discrepancies }\end{array}$ & $\begin{array}{l}\text { With at least one } \\
\text { unintentional } \\
\text { discrepancy }\end{array}$ & \\
\hline Sociodemographic & $\mathrm{N}=182$ & $\mathrm{~N}=116$ & $\mathrm{~N}=66$ & \\
\hline Age (years old) Mean (SD) & $63.0(19.4)$ & $59.0(20.5)$ & $70.0(15.0)$ & 0.003 \\
\hline Male gender ${ }^{1} \mathrm{n}(\%)$ & $115(63.2)$ & $69(59.5)$ & $34(51.5)$ & 0.375 \\
\hline Patients' home medication Mean (SD) & $4.9(3.6)$ & $4.1(3.5)$ & $6.5(3.2)$ & 0.001 \\
\hline Diagnostic hypotheses according to ICD-10 n (\%) & $\mathrm{N}=\mathbf{2 0 5}$ & $\mathrm{N}=124$ & $\mathrm{~N}=81$ & \\
\hline Diseases of the circulatory system & $85(41.5)$ & $53(42.7)$ & $32(39.5)$ & 0.753 \\
\hline Abnormal clinical and laboratory symptoms, signs and findings, not elsewhere classified & $27(13.2)$ & $19(15.3)$ & $8(9.9)$ & 0.360 \\
\hline Diseases of the genitourinary system & $21(10.3)$ & $9(7.2)$ & $12(14.8)$ & 0.131 \\
\hline Diseases of the digestive system & $14(6.8)$ & $7(5.6)$ & $7(8.6)$ & 0.583 \\
\hline Infectious and parasitic diseases & $13(6.4)$ & $10(8.0)$ & $3(3.7)$ & 0.254 \\
\hline Diseases of the respiratory system & $12(5.8)$ & $5(4.0)$ & $7(8.6)$ & 0.285 \\
\hline Injuries, poisoning and certain other consequences from external causes & $8(3.9)$ & $5(4.0)$ & $3(3.7)$ & 0.999 \\
\hline Diseases of the musculoskeletal system and connective tissue & $7(3.4)$ & $7(5.6)$ & - & - \\
\hline Mental and behavioral disorders & $5(2.4)$ & $1(0.8)$ & $4(4.9)$ & 0.081 \\
\hline External causes of morbidity and mortality & $4(1.9)$ & $3(2.4)$ & $1(1.2)$ & 0.999 \\
\hline Endocrine, nutritional and metabolic diseases & $3(1.5)$ & $2(1.6)$ & $1(1.2)$ & 0.999 \\
\hline Skin and subcutaneous tissue diseases & $3(1.5)$ & $2(1.6)$ & $1(1.2)$ & 0.999 \\
\hline Nervous system diseases & $2(1.0)$ & $1(0.8)$ & $1(1.2)$ & 0.999 \\
\hline $\begin{array}{l}\text { Blood diseases and of the blood-forming organs, and certain disorders involving } \\
\text { the immune mechanism }\end{array}$ & $1(0.5)$ & - & $1(1.2)$ & - \\
\hline Pharmacotherapy & $\mathrm{N}=900$ & $\mathrm{~N}=784$ & $\mathrm{~N}=116$ & \\
\hline \multicolumn{5}{|l|}{ Types of medications $n(\%)$} \\
\hline Cardiovascular System & $390(43.3)$ & $345(44.0)$ & $45(38.8)$ & 0.339 \\
\hline Feeding Tract and Metabolism & $181(21.1)$ & $163(20.8)$ & $18(15.5)$ & 0.231 \\
\hline Blood and blood-forming organs & $118(13.1)$ & $112(14.3)$ & $6(5.2)$ & 0.010 \\
\hline Nervous System & $115(12.8)$ & $96(12.2)$ & $19(16.4)$ & 0.273 \\
\hline Systemic hormonal preparations, excluding sex hormones and insulins & $42(4.7)$ & $34(4.3)$ & $8(6.9)$ & 0.325 \\
\hline Muscle-skeletal System & $20(2.2)$ & $15(1.9)$ & $5(4.3)$ & 0.195 \\
\hline Genitourinary System and sex hormones & $12(1.3)$ & $5(0.63)$ & $7(6.0)$ & $<0.001$ \\
\hline Respiratory System & $8(0.9)$ & $6(0.8)$ & $2(1.7)$ & 0.276 \\
\hline Sensory organs & $7(0.8)$ & $3(0.4)$ & $4(3.4)$ & 0.007 \\
\hline Anti-infectives for systemic use & $5(0.5)$ & $4(0.5)$ & $1(0.9)$ & 0.499 \\
\hline Antineoplastic and immunomodulating agents & $1(0.1)$ & - & $1(0.9)$ & - \\
\hline Dermatological & $1(0.1)$ & $1(0.1)$ & - & - \\
\hline Registration failures & $N=466$ & $N=372$ & $N=94$ & \\
\hline Physician n (\%) ${ }^{2}$ & $269(57.7)$ & $223(59.9)$ & $46(48.9)$ & 0.050 \\
\hline Absence of registration & $197(42.2)$ & $167(44.9)$ & $30(31.9)$ & 0.023 \\
\hline Incomplete registration & $62(13.3)$ & $52(14.0)$ & $10(10.6)$ & 0.394 \\
\hline Incorrect registration & $10(2.2)$ & $4(1.0)$ & $6(6.4)$ & 0.001 \\
\hline Nurse $n(\%)^{2}$ & $116(24.9)$ & $108(29.0)$ & $8(8.5)$ & $<0.001$ \\
\hline Absence of registration & $105(22.5)$ & $97(26.0)$ & $8(8.5)$ & $<0.001$ \\
\hline Incomplete registration & $4(0.9)$ & $4(1.1)$ & - & - \\
\hline Incorrect registration & $7(1.5)$ & $7(1.9)$ & - & - \\
\hline Both (physician and nurse) $n(\%)^{2}$ & $81(17.4)$ & $41(11.0)$ & $40(42.5)$ & $<0.001$ \\
\hline With at least one absence of registration failure & $61(13.1)$ & $27(7.2)$ & $34(36.2)$ & $<0.001$ \\
\hline With at least one incomplete registration failure & $18(3.9)$ & $13(3.5)$ & $5(5.3)$ & 0.835 \\
\hline With at least one incorrect registration failure & $2(0.4)$ & $1(0.3)$ & $1(1.0)$ & 0.292 \\
\hline Types of discrepancies n (\%) & $227(100)$ & $111(100)$ & $116(100)$ & \\
\hline Omission of medication & 204 (89.9) & $110(99.0)$ & $94(81.0)$ & $<0.001$ \\
\hline Divergent dose & $12(5.3)$ & $1(1.0)$ & $11(9.5)$ & 0.005 \\
\hline Divergent administration frequency & $11(4.8)$ & - & $11(9.5)$ & - \\
\hline Pharmaceutical interventions $\mathrm{n}(\%)^{2}$ & $\mathbf{N}=139$ & $\mathrm{~N}=\mathbf{2 3}$ & $\mathrm{N}=116$ & \\
\hline Accepted & $116(83.5)$ & - & $116(100)$ & - \\
\hline Not accepted & $23(16.5)$ & $23(100)$ & - & - \\
\hline
\end{tabular}

${ }^{1}$ Dichotomous variable for which the results of only one of the extracts were presented. ${ }^{2}$ Percentages calculated in relation to the total $\mathrm{N}$. 
In relation to the unintended medication discrepancies, most of them $(38.8 \%)$ were related to medications of the cardiovascular system, followed by medications acting on the nervous system $(16.4 \%)$ and on the feeding tract and metabolism (15.5\%), corroborating the results of other studies. ${ }^{15,22,23}$

It was possible to observe that the mean age in the group in which the unintended discrepancies occurred was significantly higher than in the group of patients where there were no unintentional discrepancies $(p<0.05)$. Some studies describe that advanced age and a greater number of patients' home medication have been risk factors for discrepancies in medication reconciliation. However more studies are needed to determine the causality between the factors. ${ }^{24-26}$

This study has some limitations: In the first place, it is a retrospective, non-interventionist and single-center study with a convenience sample. Only a reduced percentage of patients were analyzed by the pharmacist compared to the total that were admitted in the period, due to the pharmacist being present in the sector only during business hours 5 days a week. Likewise, there was no follow-up of the patients who went through the reconciliation process in the emergency department to determine a clinical outcome, although a number of studies have shown that the reconciliation process reduces medication errors and potential adverse events for the patients. ${ }^{27-29}$ In addition, there was no control group, that is, patients admitted to the emergency department and who were not reconciled in the sector to compare the variables involved in the present study were not analyzed.

Despite the limitations, the results can contribute to the discussion on the practice of medication reconciliation and reinforce the importance of the performance of the clinical pharmacist, especially in the setting of hospital emergency departments. The characterization of the profile of medication discrepancies and the registration failures of the patients' home medication help in directing continuing education actions to the multidisciplinary team with the objective of reducing the occurrences of failures in medication reconciliation and, thus, contribute to patient safety.

This study focused on the interventions carried out in relation to medication reconciliation, but it is important to note that the pharmacist present in the emergency department can have other duties, such as answering questions about medication information, suggesting alternatives to non-standard medications in the institution, suggesting adjustments in the dosage of prescription medications, such as dose adjustment according to renal function, infusion time and adequate dilution, contributing to better clinical outcomes in the patients. $7,8,30$ In our hospital, we have resident pharmacists for developing these activities and the possibility of allocating a pharmacist exclusively for medication reconciliation is being evaluated.

\section{Conclusion}

Since the emergency department is one of the main routes of hospital admission, the presence of the pharmacist in this sector reduced the incidence of unintentional discrepancies related to medication reconciliation, through interventions to correct medication omissions, dose adjustment and their frequency, being an important element for patient safety. Due to the study limitations, caution must be used to extrapolate the results to other settings.

\section{Funding sources}

This study is the Residency Completion Work with a grant funded by PROADI-SUS from the Ministry of Health.

\section{Collaborators}

Barbosa AV contributed in the design of the project, data analysis and interpretation, and writing of the article. Chrispim PP contributed in the design of the project and in the relevant critical review of the intellectual content. Szpak DS contributed in the relevant critical review of the intellectual content. The authors approve the final version of the manuscript and are responsible for all the information presented in the paper, ensuring the accuracy and integrity of any of its parts.

\section{Conflict of interest statement}

The authors declare that there are no conflicts of interest in relation to this article.

\section{References}

1. Conselho Federal de Farmácia (CFF). Serviços farmacêuticos diretamente destinados ao paciente, à família eà comunidade: contextualização e arcabouço conceitual. 2016. Available in: <http://www.cff.org.br/userfiles/Profar_Arcabouco_TELA FINAL.pdf>. Accessed December 26, 2020.

2. Frizon $\mathrm{F}$, dos Santos $\mathrm{AH}$, Caldeira $\mathrm{L}$ et al. Medication reconciliation at a university hospital. Rev Enferm. 2014;22(4):454-60

3. Eidelwein CR, Caldeira LF, Sanches AC. Medication reconciliation in orthopedic and neurological patients in a public hospital. Rev Bras Farm Hosp Serv Saude. 2020;11(3):0354

4. Magalhães GF, De Santos GBNC, Rosa MRB, et al. Medication reconciliation in patients hospitalized in a cardiology unit. PloS ONE. 2014;9(12):1-12

5. Tam VC, Knowles SR, Cornish PL, et al. Frequency, type and clinical importance of medication history erros at admission to hospital: a systematic review. CMAJ. 2005;173(5):510-515.

6. Dawson H, Weerasooriya J, Webster G. Hospital admissions via the emergency department: implications for planning and patient flow. Healthc Q. 2008;11(1):20-2.

7. Kent AJ, Harrington L, Skinner J. Medication reconciliation by a pharmacist in the Emergency Department: A pilot project. Can J Hosp Pharm. 2009;62(3):238-42.

8. Miranda TMM, Petriccione S, Ferracini FT, et al. Interventions performed by the clinical pharmacist in the emergency department. Einstein. 2012;10(1):74-81

9. Ivama AM, Noblat L, Castro, MS, et al. Consenso brasileiro de atenção farmacêutica: proposta. Distrito Federal, Organização PanAmericana da Saúde. 2002. Available in http://bvsms. saude.gov.br/bvs/publicacoes/PropostaConsensoAtenfar.pdf, accessed on 29 January 2021.

10. Nunes PHC, Pereira BMG, Nominato, JCS, et al. Intervenção 
farmacêutica e prevenção de eventos adversos. Rev Bras Cienc Farm. 2008;44(4):691-699.

11. Santos COL, Francieli LH, Azambuja MS, et al.Reconciliação de medicamentos: processo de implantação em um complexo hospitalar com a utilização de sistema eletrônico. Saúde Debate. 2019;43(121);368-377.

12. Schuch AZ, Zuckermann J, Santos MEF, et al. Reconciliação de medicamentos na admissão em uma unidade de oncologia pediátrica. Rev. Bras. Farm. Hosp. Serv. Saúde. 2013;4(2);3539

13. Dorneles J, Santos CO, Lima LH, et al. Medication reconciliation in admission hospitalization: retrospective study. Rev Bras Farm Hosp Serv Saude. 2020;11(2):0397.

14. Pippins JR, Gandhi TK, Hamann C, et al. Classifying and predicting errors of inpatient medication reconciliation. J Gen Intern Med. 2008;23(9):1414-22.

15. Lombardi NF, Mendes AE, Lucchetta RC, et al. Analysis of the discrepancies identified during medication reconciliation on patient admission in cardiology units: a descriptive study. Rev Lat Am Enfermagem. 2016 15;24:e2760.

16. Salanitro AH, Osborn CY, Schnipper JL, et al. Effect of patientand medication-related factors on inpatient medication reconciliation erros. J Gen Intern Med. 2012;27(8): 924-932.

17. Knez L, Suskovic S, Rezonja R, et al. The need for medication reconciliation: a cross-sectional observational study in adult patients. Respir Med. 2011 Oct;105 Suppl 1: S60-6.

18. Zaal RJ, den Haak EW, Andrinopoulou ER, et al. Physicians' acceptance of pharmacists' interventions in daily hospital practice. Int J Clin Pharm. 2020;42(1):141-149.

19. Reis WCT, Scopel CT, Correr CJ, et al. Análise das intervenções de farmacêuticos clínicos em um hospital de ensino terciário do Brasil. Einstein (São Paulo). 2013;11(2):190-6

20. Ferracini FT, Almeida SM, Locatelli J, et al. Implantação e evolução da farmácia clínica no uso racional de medicamentos em hospital terciário de grande porte. Einstein (São Paulo). 2011;9(4):456-60.

21. Choi YJ, Kim H. Effect of pharmacy-led medication reconciliation in emergency departments: A systematic review and meta-analysis. J Clin Pharm Ther. 2019;44(6):932945.

22. Zoni $A C$, Durán García $M E$, Jiménez $M u n ̃ o z ~ A B$, et al. The impact of medication reconciliation program at admission in an internal medicine department. Eur J Intern Med. 2012;23(8):696-700.

23. Spalla LR, Castilho SR. Medication reconciliation as a strategy for preventing medication erros. Braz. J. Pharm. Sci. 2016; 52(1):143-150.

24. Salameh L, Abu Farha R, Basheti I. Identification of medication discrepancies during hospital admission in Jordan: Prevalence and risk factors. Saudi Pharm J. 2018 Jan;26(1):125-132.

25. Mazhar F, Akram S, Al-Osaimi YA, et al. Medication reconciliation errors in a tertiary care hospital in Saudi Arabia: admission discrepancies and risk factors. Pharm Pract (Granada). 2017 Jan-Mar;15(1):864
26. Okerosi Okalebo FA, Opanga AS, Guantai AN. Prevalence and Risk Factors for Medication Discrepancies on Admission of Elderly Diabetics at Kenyatta National Hospital, Kenya. Afr. J. Pharmacol. Ther. 2017;6(1):54-63

27. Barnsteiner JH. Medication Reconciliation. In: Hughes RG, editor. Patient Safety and Quality: An Evidence-Based Handbook for Nurses. Rockville (MD): Agency for Healthcare Research and Quality (US); 2008 Apr. Chapter 38

28. Shah C; Barnett N. Medicines reconciliation: a patient safety priority. Prescriber. 2015; 26(1).23-26.

29. Kreckman J, Wasey W, Wise S, et al. Improving medication reconciliation at hospital admission, discharge and ambulatory care through a transition of care team. BMJ Open Qual. 2018. 20;7(2):e000281.

30. Roman C, Edwards G, Dooley M, et al. Roles of the emergency medicine pharmacist: A systematic review. Am J Health Syst Pharm. 2018. 1;75(11):796-806. 